\title{
Personality \\ and Politics
}





\title{
Personality and Politics
}

\author{
Problems of Evidence, Inference,
} and Conceptualization

With a new preface

\section{FRED I. GREENSTEIN}

Princeton Univerity Press

Princeton, New Jersey 


\section{To Amy, Jessica, and Michael}

Published by Princeton Universıty Press, 41 Willam Street, Princeton, New Jersey 08540

In the United Kingdom Princeton Unıversity Press, Guildford, Surrey

Preface to New Edition copyright (C) 1987 by Princeton University Press All rights reserved

Library of Congress Cataloging in Publication Data will be found on the last printed page of this book

First prıntıng, 1969 by Markham Publıshıng Company

Norton editıon, 1975

First Princeton Paperback printıng, 1987

LCC $87-2427$

ISBN 0-691-07731-2

ISBN 0-691-02260-7 (pbk)

Clothbound editions of Princeton University Press books are printed on acıdfree paper, and binding materials are chosen for strength and durability Paperbacks, while satısfactory for personal collections, are not usually suitable for library rebinding

Printed in the United States of America by Princeton University Press, Princeton, New Jersey 